IJBPAS, December, Special Issue, 2021, 10(12): 171-184

ISSN: 2277-4998

International Journal of Biology, Pharmacy

and Allied Sciences (IJBPAS)

'A B ridge Between Caboratory and Qando'

wWw.ijbpas.com

\title{
ENFORCEMENT OF REGIONAL REGULATIONS CONCERNING SUSTAINABLE AGRICULTURAL LAND PROTECTION IN BANJAR REGENCY
}

\author{
ANWARY I", HADIN AF, MUHJAD MH AND REDHANI ME \\ Faculty of Law, University of Lambung Mangkurat, Indonesia, Brigjen H. Hasan Basry Street Kayu \\ Tangi, Banjarmasin \\ *Corresponding Author: Dr. Ichsan Anwary: E Mail: afhadin@ulm.ac.id \\ Received 19 ${ }^{\text {th }}$ Aug. 2021; Revised 20 ${ }^{\text {th }}$ Sept. 2021; Accepted $29^{\text {th }}$ Oct. 2021; Available online $1^{\text {st }}$ Dec. 2021 \\ https://doi.org/10.31032/IJBPAS/2021/10.12.2018
}

\begin{abstract}
The problem of implementing policies to protect agricultural land for sustainable food in Indonesia is a difficult task. This is inseparable from the problem of changing the function of agricultural land to non-agricultural which continues to occur. This problem is not in accordance with Law Number 41 of 2009, which aims to guarantee the right to food as a human right of every citizen and also wants to realize food independence, resilience, and sovereignty while at the same time prospering farmers, especially the weak, including in Banjar Regency. The research method used in this paper is normative legal research, with a statutory and conceptual approach and a case approach in solving legal issues. The findings are that the normalization construction in the Banjar Regency Regional Regulation Number 9 of 2012 concerning the Protection of Sustainable Food Agricultural Land has not fully regulated the scope of the establishment of the Regional Regulation on sustainable food agricultural land. The local regulation cannot be implemented, so practically some of the norms in the local regulation cannot be implemented. As well as the achievements to the extent of land progress and the achievements of the results which are achieved by providing reports that should be submitted by the regional government of the Banjar Regency. The implication of the determination of community land that is designated as sustainable food agricultural land has consequences where the Banjar Regency Government has not been able to fulfill it. As well as the achievements to the extent of land progress and the achievements of the results which are achieved by providing reports that should be submitted by the local government of the Banjar Regency. The implication of the determination of community land that is designated as sustainable food agricultural land has consequences where the Banjar Regency Government has not been able to fulfill it. As well as the
\end{abstract}


achievements to the extent of land progress and the achievements of the results which are achieved by providing reports that should be submitted by the regional government of the Banjar Regency. The implication of the determination of community land that is designated as sustainable food agricultural land has consequences where the Banjar Regency Government has not been able to fulfill it.

\section{Keywords: Enforcement, Regional Regulation, Sustainable Agricultural Land Protection INTRODUCTION}

South Kalimantan Province in mid-January, starting on Thursday, January 14, 2021, there have been major floods for more than a week (1). Many victims who fell both in the form of property and life. Flood is the overflow of large amounts of water onto land that is usually dry. Floods occur due to many things such as excessive rain, overflowing of rivers, rivers, lakes or oceans. Floods are extremely dangerous and have the potential to wipe out entire cities, coastlines or areas and cause extensive damage to life and property. Floods also have great erosive power and can be very destructive. Banjar Regency is one of the areas worst affected by floods.

Floods of course also cause damage to crops and agricultural land so that it becomes a warning for food availability. The Banjar Regency Government through the revision of the Regional Spatial Plan (RTRW) which expands the sustainable food agriculture area to 37,209.75 hectares. Even though based on the 2013-2032 annual RTRW, the planned agricultural area was only set at $15,828.92$ hectares in 2019, the addition of this agricultural area is part of the policy strategy for protecting sustainable food agricultural land to maintain ecosystem balance. Namely by providing protection for sustainable food agricultural land in the form of planning, determination, development, research, utilization, guidance, control, supervision, information systems, protection and empowerment of farmers, financing and community participation (2).

Based on the RTRW of Banjar Regency in 2013-2032, the planned agricultural area is $15,828.92$ hectares, while based on the revised 2018 RTRW, the plan for sustainable food agriculture is $37,209.75$ hectares (3). There is also no denying that the increase in the number was due to the large number of agricultural lands that have been converted to nonagricultural functions. This has an impact on the protection of sustainable food agricultural land and the fulfillment of community rights to food. To fulfill the community's right to food, the Banjar Regional Government has implemented several policies to ensure food availability. These policies are in the form of printing new rice fields, diversifying food, providing labor-intensive programs in the form of training in sasirangan skills, the use of modern agricultural tools, and improving the fulfillment of water needs for agriculture (4).

Strategic efforts in controlling the conversion of agricultural land and protecting productive agricultural land need to be supported by a statutory regulation (5). To protect food agricultural land continuously, the provisions of 
Law Number 41 Year 2009 concerning the Protection of Sustainable Agricultural Land have been established (6). This provision needs to be further elaborated by the Regional Government as it is determined that the Regency/City Province determines sustainable food agricultural land, one of which is the obligation to designate agricultural areas in the Regional Spatial Planning so that its existence is expected to be sustainable.

Banjar Regency itself has a Banjar Regency Regional Regulation Number 9 of 2012 concerning the Protection of Sustainable Food Agricultural Land (7). In CHAPTER VIII CONTROL Part One stipulates Article 37 (1) Control of Sustainable Food Agricultural Land is carried out in a coordinated manner. (2) The Regional Government appoints the Head of Service to coordinate the control as referred to in paragraph (1). Meanwhile, Article 38 Control of Sustainable Food Agricultural Land is carried out by the Regional Government through the provision of:

a. Incentive;

b. Disincentives;

c. Licensing mechanism;

d. Protection; and

e. Counseling

In CHAPTER XI which regulates Administrative Sanctions Article 70 (1) Anyone who violates the obligations or prohibitions as referred to in Article 35, Article 54, Article 62 paragraph (2), Article 69 paragraph (3) is subject to administrative sanctions. The strong legal basis and pro-policy towards the sustainability of agricultural land in reality are still not commensurate with the high rate of residential development and the peak of major floods.

The problem of implementing policies to protect agricultural land for sustainable food in Indonesia is a difficult task. This is inseparable from the problem of changing the function of agricultural land to non-agricultural which continues to occur. This problem is not in accordance with Law No. 41 of 2009, which aims to guarantee the right to food as a human right of every citizen and also wants to realize self-reliance, security, and food sovereignty while at the same time prospering farmers, especially the weak.

\section{RESEARCH METHODS}

The research method used in this paper is normative legal research, with a statutory and conceptual approach as well as a case approach in solving legal issues in an analytical description regarding Enforcement of Regional Regulations on Sustainable Agricultural Land Protection in Banjar Regency (8).

\section{ANALYSIS AND DISCUSSION}

\section{Overview of Research Area}

The Banjar Regency Government on July 11, 2012 stipulates the Banjar Regency Regional Regulation Number 9 of 2012 concerning the Protection of Sustainable Food Agricultural Land (Banjar Regency Regional Gazette of 2012 Number 9). This Regional Regulation is a mandate from Article 25 of Law Number 41 of 2009 concerning Protection of Sustainable Food Agricultural Land (Law Number 41 of 2009 has several articles amended by Law Number 11 of 2020 concerning Job Creation). 
The purpose of the stipulation of this Regional Regulation is to realize and ensure the availability of fertile food agricultural land, to realize self-reliance, national food security and sovereignty, to increase the empowerment and welfare of farmers, to provide certainty in farming and to realize ecological balance and to prevent wasting investment in agricultural infrastructure.

Stipulation of District Regulation. Banjar Number 9 of 2012 concerning PLP2B cannot be separated from the consideration that Banjar Regency is known as one of the rice producers and suppliers for most of South Kalimantan, even its agricultural products are also sent to meet the rice needs of other regions such as Central Kalimantan, East Kalimantan, and several regions. area on the island of Java. Various agricultural development programs are implemented by the Banjar Regency Government to achieve food self-sufficiency through the food crops, livestock and fisheries sub-sectors.

With reference to that time, data from the Department of Agriculture, Plantation and Livestock shows that rice production from 2005 to 2009 has decreased. This is due to many farmers experiencing crop failure due to flooding (9).

Taking into account that the agricultural sector has a strategic and significant role in the national and regional economy. Some of the roles referred to are contributions to Gross Domestic Product (10), food and feed providers, sources of foreign exchange, providers of industrial raw materials and sources of bio-energy, employment, poverty alleviation and increasing people's income (11). Rice is the main food commodity of Banjar Regency which stands out. Within the scope of South Kalimantan Province, Banjar Regency is one of the centers of rice production which contributes very significantly to the total rice production of South Kalimantan. The position of the production center is only surpassed by Barito Kuala Regency, which ranks first (12). Banjar Regency as the largest agrarian center in South Kalimantan Province needs to ensure the provision and protection of fertile food agricultural land as a source of employment and a decent livelihood for humanity. independence, resilience, and national food sovereignty. On the other hand, philosophically, land has a central role and function for the Indonesian people who are agrarian because they have economic, socio-cultural and religious values.

So far, various policies related to controlling the conversion of agricultural land, especially irrigated rice fields, have been issued in the form of laws and regulations, but their implementation is not effective because these laws and regulations do not contain criminal sanctions. In addition, the Government and Regional Governments are not really serious about implementing it.

Law Number 41 of 2009 was followed up by several implementing regulations in the form of government regulations such as:

1. Government Regulation Number 1 of 2011 concerning the Determination of the 
Transfer of Functions of Sustainable Agricultural Land.

2. Government Regulation Number 12 of 2012 concerning Incentives for Protection of Sustainable Food Agricultural Land.

3. Government Regulation Number 25 of 2012 concerning Sustainable Food Agricultural Land Information System.

4. Government Regulation Number 30 of 2012 concerning Financing for the Protection of Sustainable Food Agricultural Land.

With the regional legal politics set by the Banjar Regency Government through the Banjar Regency Regional Regulation No. 9 of 2012 concerning the Protection of Sustainable Food Agricultural Land (PLP2B), it is necessary to begin measurable and planned steps in the agricultural sector, especially in efforts to protect sustainable food agricultural land in Banjar Regency. The Sustainable Food Agricultural Land Protection Plan contains policies, strategies, program indications, as well as programs and financing plans related to the Sustainable Food Agricultural Land Protection plan which is the content of the Long Term Development Plan (RPJP), Medium Term Development Plan (RPJM), and district annual.

Aspects of Formulation of Regional Regulation Norms

The structure of the Banjar Regency Regional Regulation Number 9 of 2012 contains 14 chapters, 74 articles, consisting of:

1. Chapter I General Provisions

2. Chapter II Principles, Objectives and Scope
3. Chapter III Determination of Sustainable Agricultural Land

4. Chapter IV Development

5. Chapter V Research

6. Chapter VI Utilization

7. Chapter VII Coaching

8. Chapter VIII Control

9. Chapter IX Land Use for Sustainable

Food Agriculture

10. Chapter X Supervision

11. Chapter XI Administrative Sanctions

12. Chapter XII Criminal Provisions

13. Chapter XIII Transitional Provisions

14. Chapter XIV Closing Provisions.

Observing the Scope of this Regional Regulation as regulated in Chapter II, Article 4 determines the scope of protection for sustainable food agricultural land:

a. Planning and determination;

b. Development;

c. Study;

d. Utilization;

e. coaching;

f. Control;

g. Supervision;

h. Information Systems;

i. Protection and empowerment of farmers;

j. Financing; and

k. Community participation.

Article 4 of the Regional Regulation above is an article adopted from Law Number 41 of 2009 concerning the Protection of Sustainable Food Agricultural Land. It is regulated in Article 5 concerning the scope of this Regional Regulation which includes the determination of 
sustainable food agricultural land and the transfer of functions of sustainable food agricultural land.

When observing the provisions of Article 5 letter a. Regarding the scope of the Banjar Regency Regulation which includes the determination of sustainable food agricultural land and the conversion of sustainable food agricultural land, the scope of this Regional Regulation is very limited, only regulating one part. However, it turns out that this Regional Regulation also adopts and regulates the stages of the scope as regulated in Article 4 of Law Number 41 of 2009 concerning the Protection of Sustainable Food Agricultural Land.

Thus in the structure of the substance of the District Regulation. Banjar Number 9 of 2012 contains errors that do not completely regulate what should be in the scope of protection of sustainable food agricultural land as determined by Article 4 of Law Number 41 of 2009 . Weaknesses in the structure and substance of the Regional Regulation of the Banjar Regency Government Number 9 of 2012 is not complete refers to government regulations derived from Law Number 41 of 2009. In which only one government regulation is referred to, namely PP Number 1 of 2011 concerning the Determination and Transfer of Land Functions for Sustainable Food Agriculture. For example, Government Regulation No. 30 of 2012 concerning Financing for the Protection of Sustainable Food Agricultural Land.

Constraints to Planning and Determination of Sustainable Food Agricultural Land
Based on the provisions of Article 72 local regulation of Banjar Regency Number 9 of 2012 stated that the Spatial Planning of the Regency which has not determined the Sustainable Food Agriculture Area, Sustainable Food Agricultural Land and Sustainable Food Reserve Land as referred to in Article 7 shall be adjusted no later than 1 (one) year from the promulgation of this Regional Regulation. Article 72 Regional Regulation of the District. Banjar Number 9 of 2012 On the date the Banjar Regency Government stipulates the Banjar Regency Regional Regulation Number 3 of 2013 concerning the Banjar Regency Spatial Plan (RTRW) 2013-2032 (Banjar Regency Regional Gazette of 2013 Number 3, Supplement to the Banjar Regency Regional Gazette Number 3). In the Regional Regulation of Banjar Regency Number RTRW in the arrangement of the allotted agricultural area consists of:

a. Food crop cultivation area;

b. Horticultural cultivation area;

c. Plantation cultivation area;

d. Livestock cultivation area; and

e. Sustainable food agriculture area.

Regional Regulation of Banjar Regency Number 3 of 2013 concerning the Regional Spatial Plan (RTRW) of Banjar Regency in 2013-2032 stipulates that sustainable food agriculture areas are located in six sub-districts namely Aluh-Aluh District, Gambut District, Kertak Hanyar District, Lucky Baru District, District Tabuk River and Tatah Makmur Subdistrict are in accordance with the potential and functional allocation for rice in wet and dry 
lands of approximately 15,828 (fifteen thousand eight hundred and twenty eight) hectares.

For land that is reserved for sustainable food agriculture, there are six sub-districts, namely West Martapura District, Sungai Tabuk District, Astambul District, Mataraman District, and Simpang Empat District and Karang Intan District.

Although the Banjar Regency RTRW Regional Regulation stipulates that the area of both wet and dry land is approximately 15,828 hectares covering 6 (six) sub-districts, there is no detailed information on how much each subdistrict is. There is no data on the spatial data of the area to be designated as sustainable agricultural food land.

Likewise, the size of the land reserved for sustainable food agriculture in the 6 (six) subdistricts above has not been determined. This data is important to achieve what is stated by the Banjar Regency Regional Regulation Number 9 of 2012 concerning PLP2B.

In addition, that in the sub-districts designated as sustainable food agriculture areas and for land that is reserved as sustainable food agricultural land based on the RTRW Regional Regulation it is also designated as other areas such as PKLp, among others the Peat City Kertak Hanyar; Sungai Tabuk Urban; Aluh-aluh City.

Based on the spatial structure plan for the Banjar Regency area, activity centers, main infrastructure network systems, and other infrastructure network systems are also determined. Thus, it must be prepared and determined on the Detailed Spatial Plan. Based on Regional Regulation Number 9 of 2012 that the protection of sustainable food agricultural land is a system and process in planning and establishing, developing, utilizing and fostering, controlling, and monitoring food agricultural land and its area continuously. The determination of sustainable food agricultural land includes:

a. Sustainable Food Agriculture Area;

b. Sustainable Food Farms; and

c. Sustainable Food Agricultural Reserves.

Determination of the 3 (three) things above must meet the criteria and requirements as well as the procedure for determining which is determined by the laws and regulations. Observing one part of the provisions of Regional Regulation Number 9 of 2012 for example in the determination procedure which confirms that land located in 1 (one) area that has complied with the criteria and requirements is compiled in the form of a proposal for determining regional sustainable food agriculture land.

The proposal for land designation must contain textual, numerical, and spatial data and information regarding indications of standard area at the district level to realize food selfsufficiency, security and sovereignty. One more thing that is determined by the legislation is that the proposal for land designation is prepared by taking into account the suggestions and responses of the community. Regarding the stages as described above, until now the Banjar Regency Government has not been able to fulfill them. So that the practical 
implementation and enforcement of the District

Regulation. Banjar Number 9 of 2012 concerning the Protection of Sustainable Food Agricultural Land has not yet been realized.

Based on the research that the reason for the stipulation of sustainable food agricultural land in Banjar Regency is because the implications of the determination of community land that have been determined have consequences where the Regency Government of Banjar Regency has not been able to fulfill it. This is related to the regulation on land use change on land designated as Sustainable Food Agricultural Land which can only be carried out for public interest and/or national strategic projects, where other functions are not permitted.

The community refuses to have their rice fields designated as sustainable food agricultural land with economic considerations. For the community/farmers that agricultural land/rice fields for them have economic value because at any time it can be sold for their own interests such as selling rice fields/agricultural land to go on Umrah or Hajj pilgrimages, and other economic interests. Because agricultural land / rice fields are the rights of the owner of the land / rice fields.

With regard to the regulation on incentives, it is intended that local governments provide incentives for agricultural land designated as sustainable food agricultural land, such as land and building tax relief, agricultural infrastructure development, provision of agricultural production facilities and infrastructure.
By referring to the old laws and regulations (because the new one is based on Law Number 11 of 2020 concerning Job Creation with its implementing regulations), then based on Article 59 of Government Regulation Number 15 of 2010 concerning Spatial Planning, the RTRW of Banjar Regency must determine part of the area. districts for which the RDTR needs to be drawn up. Part of the RDTR is an urban area or a district strategic area. District strategic areas can be prepared by RDTR, if they are:

a. Areas that have urban characteristics or are planned to become urban areas; and

b. Meets the criteria for the scope of the RDTR planning area determined according to applicable regulations.

Meanwhile, the instrument for determining the RDTR was stipulated by a Regional Regulation, making it difficult to draw up and reach an agreement between the Regional Government and the DPRD on the substance of the Regional Regulation on RDTR. Compared to the current regulatory instrument, it can only be stipulated by a Regional Head Regulation, in this case a regent's regulation.

Referring to the document of the Amendment to the Strategic Plan of the Office of Food Crops and Horticulture of Banjar Regency Year 2016 - 2021, which is the direction and guideline for the implementation of programs and activities as well as performance indicators of annual targets for the Office of Horticultural Food Gardens in carrying out its duties and functions, especially within a period of 5 (five) years. which refers to the Revised RPJMD 2016-2021 (13). 
The issue of the achievements of the Banjar Regency Regional Regulation Number 9 of 2012 concerning the Protection of Sustainable Food Agricultural Lands is not mentioned but only mentions in general the not yet optimal planting area of food crops and horticulture, and the not yet optimal productivity of food crops and horticulture. Where the strategic issues that can be identified based on the results of the SWOT analysis, the study of the Vision and Mission of Banjar Regency as well as the duties and functions of the Food Crops and Horticulture Office are not yet optimal production of food crops and horticulture (14).

The above problems are closely related to very strategic policies regarding the determination of sustainable food agricultural land and regulation of the conversion of food agricultural land functions.

\section{RTRW Banjar Regency 2021 - 2041}

As an implication of the enactment of Law Number 11 of 2020 concerning Job Creation, one of which is to make changes to several provisions in Law Number 26 of 2007 concerning Spatial Planning (State Gazette of the Republic of Indonesia of 2007 Number 68, Supplement to the State Gazette of the Republic of Indonesia Number 4725), on 7 July 2021, the Banjar Regency Government stipulates the Banjar Regency Regional Regulation Number 4 of 2021 concerning the Banjar Regency Spatial Plan for 2021 - 2041 (Banjar Regency Regional Gazette of 2021 Number 4) which replaces the Banjar Regency Regional Regulation Number 3 of 2013 concerning Banjar Regency Spatial Planning
2013 - 2032 (Banjar Regency Regional Gazette 2013 Number 3, Supplement to Banjar Regency Regional Gazette Number 3).

Based on the Banjar Regency Regional Regulation Number 4 of 2021 concerning the RTRW Banjar Regency 2021-2041 which is new, then regarding the Determination of Strategic Areas in Banjar Regency consisting of National Strategic Areas, Provincial Strategic Areas and Regency Strategic Areas. Strategic Area Plans are depicted on a map with an accuracy of 1:50,000 (one to fifty thousand).

The Regency Strategic Areas consist of:

a. Areas that have strategic value from the point of view of the importance of economic growth; and

b. Areas that have strategic value from the point of view of socio-cultural interests. For strategic areas from the point of view of the importance of economic growth consists of:

c. The industrial designation area for the South Ring Road includes Kertak Hanyar District, Gambut District, Tatah Makmur District, Aluh-aluh District, Lucky Baru District;

d. Protected areas for sustainable food crop agriculture (rice development), horticulture and food crops include Gambut District, Kertak Hanyar District, Lucky Baru District, Tatah Makmur District, Aluh-Aluh District, West Martapura District, East Martapura District, Martapura District, Sungai Tabuk District, Astambul District, Mataraman District, Simpang Empat District, Cintapuri Darussalam District, 
Connect Makmur District and Pengaron

District; and

e. Aquaculture areas include Martapura

District, West Martapura District, Aluh-

Aluh District, Aranio District and Karang Intan District.

According to the new RTRW Regional Regulation, the Banjar Regency Government determines the RDTR, as the operationalization of the Regional RTRW. The RDTR as intended is prepared for PKW, PKL and PPK as well as other areas according to the need and urgency of handling. RDTR is stipulated in a Regent Regulation in accordance with Article 18 of the amendment to Law Number 26 of 2007 concerning Spatial Planning as amended by Law Number 11 of 2020 concerning Job Creation. Article 18 paragraph (1) The Regent/Mayor is obligated to stipulate a draft regulation of the head of the regency/municipality regarding detailed spatial planning plans no later than 1 (one) month after obtaining substance approval from the Central Government.

Achievements of the Regional Regulation on the Protection of Sustainable Food Agricultural Land

Based on the period since the stipulation of Regional Regulation of Banjar Regency Number 9 of 2012 concerning Protection of Sustainable Food Agricultural Land, of course there must be achievements and indicators that can be used as benchmarks to assess and evaluate the success of the implementation of the said Regional Regulation Number 9 of 2012.
With reference to the RPJMD of Banjar Regency 2016-2021 which substantially cannot be separated from the regional motto to reflect the determination and high spirit of the people of Banjar Regency in participating in continuing and improving the development of the Banjar region based on Faith and Taqwa, Family Spirit and Mutual Cooperation.

One of the development missions (Third Mission) of Banjar Regency is to improve the management of natural resources based on agriculture, plantations, livestock, fisheries and other regional superior commodities with an environmentally friendly Agribusiness and industrial approach. From the mission above, the objectives to be achieved include increasing agricultural production and productivity, increasing food security. With the target, among others, in the agricultural sector is to increase agricultural production and productivity.

In the context of the Third Mission above, the Strategy and Direction of the Banjar Regency Regional Policy in, among others, are:

a. increase the quantity and quality of agricultural land;

b. increase the ratio of land ownership and the ability of farmers to cultivate land;

c. strengthen district government policy support;

d. improving the quality of agricultural planning;

e. enforcement of the RTRW regional regulation, orderly and consistently order licensing to control the conversion of agricultural land. 
The weakness acknowledged by the local government of Banjar Regency because it does not have real data, only sees the reality that occurs due to land use change, the food production center of Banjar Regency is shrinking. The area of Banjar Regency's agricultural land is decreasing day by day due to changing its function into a residential area, shops and public areas. That the data on the area of agricultural land in Banjar Regency has never changed, namely 67 thousand hectares. But the area of rice fields has shrunk to only 50 thousand hectares.

Based on the RTRW Kab. Banjar Year 2013 2032 which places Sustainable Food Agricultural Land only contains its area. The detailed arrangement of the area in the form of spatial data has not been clearly regulated, this of course has implications in its application. One of the obstacles to the application of the land area. is the difference in data on agricultural land area between satellite imagery by the Ministry of Agriculture, Ministry of Public Works and Public Housing, Central Bureau of Statistics, and Regency Bappeda.

As a form of the Banjar Regency Government's commitment to maintain Banjar Regency as a rice barn or Kindai Limpuar, it is carried out by establishing a sustainable food agricultural land area in the revised RTRW of Banjar Regency which is projected to be 211,651 ha spread over 11 sub-districts. West Martapura, Lucky Baru, Tatah Makmur, Martapura City, Aluh Aluh, Karang Intan District, Astambul and East Martapura.
This is for Banjar Regency as a food buffer, where Banjar Regency is kindai limpuar. Aspects of supervision and reporting. Based on the provisions of Article 67 of the Regional Regulation Number 9 of 2012 concerning the Protection of Sustainable Food Agricultural Land, the supervision includes:
a. reporting;
b. monitoring;
c. evaluation

The said report is also public information that is announced and can be accessed openly by the public in accordance with the provisions of the applicable laws and regulations. Monitoring and evaluation is carried out by observing and checking reports with implementation in the field. In the event that the results of the monitoring and evaluation prove that there are deviations, the Regent is obliged to take steps to resolve it in accordance with the provisions of the legislation. Because if later the Regent does not carry out the settlement steps, the Regent will be subject to action according to the legislation.

By taking the indicators for the 2018 Banjar Regent Accountability Report, especially Agricultural Affairs described from pages 362 to page 378 , there are no reports on / regarding the implementation, evaluation and results achieved regarding the protection of sustainable food agricultural land in Banjar Regency. Similarly, reviewing the 2020 Banjar Regent's Accountability Report, in matters of choice in the agricultural sector, which is described from pages 393 to page 417, the achievements of implementing programs and special activities 
for mandatory non-basic services, there are no information and reports on the achievements and evaluations of sustainable agricultural land protection and its effect on agricultural products.

Thus, of course there are things that are scattered or forgotten to provide information reports regarding the progress and evaluation of the protection of sustainable agricultural land where data and reports should be provided by the Department of Agriculture, Food Crops and Horticulture as the leading sector. Observing the 2018 Banjar Regent's Accountability Report, in particular the matter of choice in this case agriculture in the analysis of the suitability between activities and program performance targets that have been set in the work agreement, there is no mention of sustainable agricultural land. Achievements of Agricultural Affairs described from page 362 to page 378 there are no reports on / regarding the implementation and results achieved as the implementation of the District Regulation Banjar Number 9 of 2012.

Based on the analysis of the various documents mentioned above which do not mention the achievements of the implementation of the District Regulation. Banjar No. 9 of 2012 because it is Banjar Distric Government has not been able to determine the protection of sustainable food agricultural land in Banjar Regency. Supposedly since the enactment of the District Regulation. Banjar Number 9 of 2012 was then followed up with the establishment of a Regional Regulation on the RTRW of Banjar Regency in 2013. Then the next instrument that must be stipulated is the RDTR regulation. So that the considerations, purposes and objectives of the stipulation of the District Regulation. Banjar Number 9 of 2012 can be implemented even though there may be obstacles in its implementation.

\section{Aspects of Socialization and Supervision of Regional Regulations}

Law Number 23 of 2014 concerning Regional Government affirms in Article 254: (1) Regional heads are obliged to disseminate local regulation that have been promulgated in regional gazettes and Regional Head Regulation that have been promulgated in regional news. (2) Heads of regions who do not disseminate regional regulations and regional regulations that have been promulgated as referred to in paragraph (1) are subject to administrative sanctions in the form of a written warning by the Minister for governors and by governors as representatives of the central government for regents/mayors. (3) In the event that the written warning as referred to in paragraph (2) has been delivered 2 (two) times in a row and is still not implemented, That the Banjar Regency Regional Regulation Number 9 of 2012 has not been able to be socialized to meet the provisions stipulated in the Regional Government Law. This can be seen from the time indicator that until now (in a fairly long period of time since 2012) it has not been possible to determine sustainable food agricultural land according to the provisions of the stipulation of the Banjar Regency Regional Regulation on the Protection of Sustainable Food Agricultural Land whose purpose is to 
realize and ensure the availability of land. sustainable food agriculture, controlling the conversion of sustainable food agricultural land functions, and realizing regional food selfreliance, resilience and sovereignty.

\section{CONCLUSION}

The normalization construction in the Banjar Regency Regional Regulation Number 9 of 2012 concerning the Protection of Sustainable Food Agricultural Land has not fully regulated the scope of the establishment of the Regional Regulation on sustainable food agricultural land. Because it does not completely adopt and adjust in the local regulation on Law Number 41 of 2009 concerning the Protection of Sustainable Food Agricultural Land, and various implementing regulations. As a result, the regulation is difficult to implement.

That since the stipulation of the District Regulation. Banjar Number 9 of 2012 concerning the Protection of Agricultural Land for Sustainable Food Up to now the Regional Regulation cannot be implemented, so that practically some of the norms in the Regional Regulation cannot be implemented. As well as the achievements to the extent of land progress and the achievements of the results which are achieved by providing reports that should be submitted by the regional government of the Banjar Regency.

Based on research findings that the reason for the stipulation of Sustainable Food Agricultural Land in Banjar Regency is because the implications of the determination of community land designated as sustainable food agricultural land have consequences where the Banjar
Regency Government has not been able to fulfill it. This is closely related to the provision of incentives by the Regional Government. Other matters relating to regulations regarding land use change on land designated as Sustainable Food Agricultural Land can only be carried out for the public interest and/or national strategic projects, ${ }^{\mathrm{i}}$ where the transfer of other functions is not allowed. Land for the community has economic value because at any time it can be sold for their own interests so that there is a reluctance to set it as a sustainable food cropland.

\section{ACKNOWLEDGEMENT}

Thanks are conveyed to all parties who have helped in completing this research, especially related agencies and stakeholders who provide information in interviews. In addition, thanks were also conveyed to the Research and Community Service Institute of Lambung Mangkurat University which provided funding in this study based on Lecturer Program Must Research with PNBP University Financing Scheme in Lambung Mangkurat University Environment Fiscal Year 2021 Cluster Madya Number: 009. $136 / \mathrm{UN} 8.2 / \mathrm{PL} / 2021$.

\section{REFERENCES}

[1] https://www.bbc.com/indonesia/indonesia55696841

[2] Anneke Puspasari, 2012, Factors Affecting the Transfer of Agricultural Land Functions and Its Impact on Farmers' Income (Case Study of Kondang Jaya Village, East Karawang District, Karawang Regency), Bogor: Thesis of the Department of Resource and 
Environmental Economics, Faculty of Economics and Management, IPB.

[3] https://banjarmasin.tribunnews.com/2019/ 07/19/revisi-rtrw-kabupaten-banjarkawasan-pertanian-di-banjar-bermbahwide

[4] Geertz, Clifford. 1963. Agricultural Involution The Process of Ecological Chenge. Berkeley: University of California Press.

[5] Misbahul Munir, 2008. The Effect of Agricultural Land Conversion on the Level of Welfare of Farmer Households (Case of Candimulyo Village, Kertek District, Wonosobo Regency, Central Java Province), Bogor: Thesis of Communication and Community Development Study Program, Faculty of Agriculture, IPB

[6] Law Number 41 of 2009 concerning the Protection of Sustainable Food Agricultural Land

[7] Banjar Regency Regional Regulation Number 9 of 2012 concerning Protection of Sustainable Food Agricultural Land

[8] Hadin Muhjad and Nunuk Nuswardani. 2012. Research on Contemporary Indonesian Law. Yogyakarta: Genta Publishing
[9] Nana Apriyana. 2011. Agricultural Land Conversion Policy in Order to Maintain Food Security, Case Study on Java Island, Ministry of National Development Planning/Bappenas, Jakarta.

[10] FAO 1997. A framework for land evaluation. II.RI Publ 22. Wageningen. viii

[11] Irawan, B. 2005. Conversion of Rice Fields: Potential Impacts, Utilization Patterns and Factors

[12] Evaluation of 2016 RKPD Implementation and Performance Achievement of Banjar Regency Government Administration, p. 25

[13] RENSTRA OF FOOD CROP AND HORTICULTURE DEPARTMENT OF BANJAR REGENCY 2017 - 2021 Banjar Regency

[14] RENSTRA OF FOOD CROP AND HORTICULTURE DEPARTMENT OF BANJAR REGENCY 2017 - 2021 Banjar Regency

[15] Maria SW Sumarjono. 2008 Land in the Perspective of Economic, Social and Cultural Rights, Kompas Gramedia, Jakarta 